\title{
P02.162. Parental interest in integrative care for children with attentional concerns
}

\author{
K Kemper ${ }^{*}$, B Banasiewicz \\ From International Research Congress on Integrative Medicine and Health 2012 \\ Portland, Oregon, USA. 15-18 May 2012
}

\section{Purpose}

Many families seek natural therapies for children. We describe what families want when they seek consultation for natural therapies for children with ADHD.

\section{Methods}

For new patients seen in an integrative pediatric clinic between $1 / 2010$ and $6 / 2011$, we reviewed intake forms, physician reports, and laboratory studies.

\section{Results}

Of the 75 new patients, 23 (31\%) families had concerns about ADHD. Of these, 70\% were male; the average age was $11.2 \pm 3.1$ years; and $80 \%$ also received care from specialists. Eleven patients $(48 \%)$ were taking a prescription medication, but only 3 (13\%) were taking medicine for ADHD; dietary supplements were taken by 12 patients (52\%). Most families were interested in health promotion information about diet (87\%), exercise (78\%), stress management (74\%), and sleep (74\%). Of 11 patients tested, $82 \%$ had low ferritin. Recommendations focused on health promotion (100\%), dietary supplements such as multivitamins/minerals (71\%) and omega-3 fatty acids (82\%), and specialist referrals (30\%).

\section{Conclusion}

Families seeking natural therapies for children with ADHD have needs for health promotion and care coordination that are well addressed using tools and skills already present in the medical home.

Published: 12 June 2012

Wake Forest University Health Sciences, Winston-Salem, USA
doi:10.1186/1472-6882-12-S1-P218

Cite this article as: Kemper and Banasiewicz: P02.162. Parental interest in integrative care for children with attentional concerns. $B M C$ Complementary and Alternative Medicine 2012 12(Suppl 1):P218.
Submit your next manuscript to BioMed Central and take full advantage of:

- Convenient online submission

- Thorough peer review

- No space constraints or color figure charges

- Immediate publication on acceptance

- Inclusion in PubMed, CAS, Scopus and Google Scholar

- Research which is freely available for redistribution

Submit your manuscript at www.biomedcentral.com/submit

\section{() Biomed Central}

\section{() Biomed Central}

(c) 2012 Kemper and Banasiewicz; licensee BioMed Central Ltd. This is an Open Access article distributed under the terms of the Creative Commons Attribution License (http://creativecommons.org/licenses/by/2.0), which permits unrestricted use, distribution, and reproduction in any medium, provided the original work is properly cited. 